\title{
The Analysis of Hotel Linen Cleaning Standard in Housekeeping Department
}

\author{
Neni Rohaeni*, Shofa Fithriturrohmi Yusuf, Yoyoh Jubaedah, Moni Sunarsih \\ Department of Home economics \\ Universitas Pendidikan Indonesia \\ Bandung, Indonesia \\ *nenirohaeni@upi.edu
}

\begin{abstract}
This research is based on the needs of performance analysis assessment of standardized Hotel's linen cleaning in Housekeeping Department, so the assessment for the competence's achievement of students during field practice can be objectively measured. The purpose of this research is to analyze the performance assessment of hotel's linen cleaning in Housekeeping Department by the stakeholder whether it is from vocational high school or the Hotel Industry. This research was using the analytic descriptive method by choosing the research respondent consisted of Hotel Accommodation's teacher and Hotel's instructor as field practice mentor for the student in related vocational. The Result shows that: (1) Performance Assessment of Hotel's linen cleaning was developed in accordance to Standard Operational Procedure that covers preparation, process and result, (2) the result of expert judgment performance assessment of hotel's linen cleaning shows a very worthy criteria so that it can be used by teacher and hotel instructor to assess the student during the practice of hotel's linen cleaning in housekeeping department.
\end{abstract}

Keywords-performance assessment, linen, laundry, housekeeping department

\section{INTRODUCTION}

Hotel accommodation skill competence in vocational high school, demands its students to possess the knowledge, attitude and skill in the housekeeping department, so the students could compete in Hotel Industry. Students must possess comprehensive competence according to their field of expertise so that they are able to compete in the Industry of Hotel and such [1]. Housekeeping Department is divided into several sections, which are room section, public area section, laundry section, pool attendant, florist, and gardening. The division of hotel sections aims to maintain the smooth running of the hotel daily operations [2]. Hotel's operation is asked to professionally provide satisfying services for the consumer [3].

Laundry is Hotel Department responsible for all cleaning, whether it is guest house clothes, employee uniform or hotel's laundry and the cleaning for everything outside the hotel or Outside Laundry [4]. Laundry is one of the required competences that the student has to master during the learning process. The practical lesson has a very important role, through the practical lesson, the students are hoped to be able to optimally master the skill [5]. Linen's role is very important in the operation of hotel. The smoothness of hotel operation will impact the hotel performance, with the hotel operation being smooth; the guest will also feel a very well done and optimal service. The process of Hotel's linen cleaning starts from the phase of collecting dirty linens, transportation, sorting, spotting, washing/extracting, drying, folding, and putting cleaned linen [6]. The potential development possessed by the student in conducting the practice can be found out through performance assessment [7]. It is then necessary for a performance assessment instrument to be had to see the competence of students in handling hotel's linen [8].

Performance assessment is a scoring instrument by asking the students to show their knowledge or skill that has been learned through work [9]. Also, performance assessment helped students to acquire answer about what it is they're demonstrating [10]. The practical assessment can be reference for teacher to make sure that the evaluation being made do not produce mistake and decide various skills that can shape the characteristic of students [11]. With this performance assessment, the teachers can objectively decide student's achieved competence [12]. The developed instrument has to refer to Hotel SOP that covers preparation, process, and result in accordance to the demands of Industry world that has been formulated in Standard National Competencies [13,14]. Therefore, it is necessary to analyze the performance of hotel linen cleaning performance in the Department of Housekeeping.

\section{RESEARCH METHODS}

The method used in this research is Descriptive Analysis. The location of this research is in SMK 9 Bandung, majoring in hotel accommodation. Participants in this study consisted of internal and external. The internal participant chosen from vocational high school as the experts of housekeeping subject. The external participant chosen from the hotel industry as the experts of housekeeping and the Academics as experts of Performance Assessment. The number of participants involved in this study were 3 people, consisting of one academic 
validators as assessment experts; one academic validators for housekeeping experts; and one practitioner validator for housekeeping experts in hotel industry. The instrument in this research is the validation format that will be used during expert judgment. The procedure of this research is going through the preparation stage, processing stage, reporting stage, and finishing stage. The data analysis techniques conducted in this research are data processing and data interpretation according to validation result [15]

\section{RESULTS AND DISCUSSION}

Performance Assessment to score competencies achievement of Students in vocational high school in laundry competence has to refer to SOP in Housekeeping Department that covers sorting process, using the material and laxative until the folding procedure and putting linen [16]. Figure including the explanation and handling procedure of Hotel's linen [17] can be seen in Figure 1:

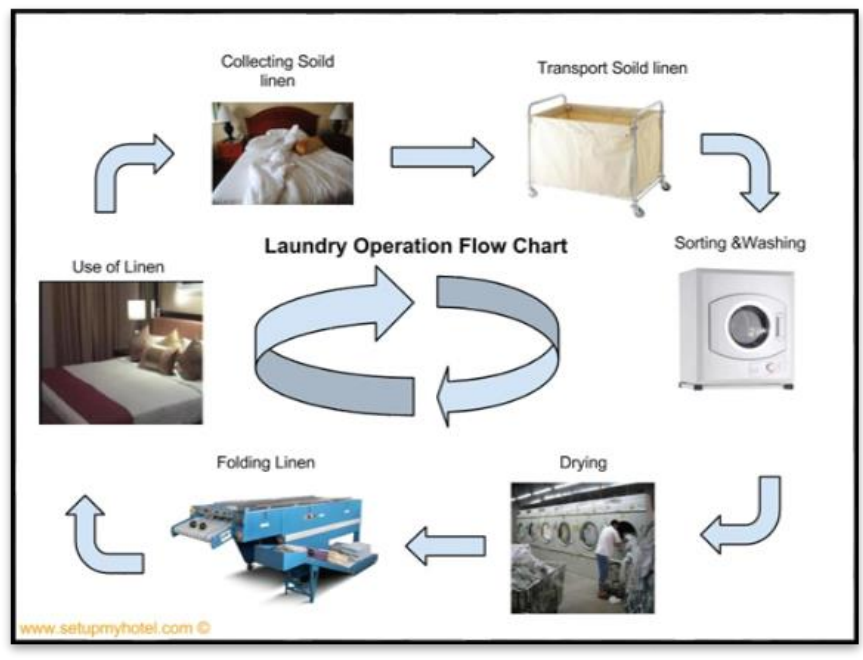

Fig. 1. Laundry operation flow chart.

Figure 1 explaining the procedure of linen cleaning that will be developed to be indicator of performance assessment instruments in the form of reference of student's performance assessment observation during the competence test of laundry in Housekeeping Department. The achieved competence assessment was conducted according to Laundry Operational that has to be done procedurally starting from Collection, Transport Soiled Linen, Sorting of linen, washing/extracting, and Drying, Ironing, Pressing [6]. Professional Laundry Services in the Hotel Industry will contribute to the customer's satisfaction for fulfilling the linen service as hotel's facility [18].
Success indicator to decide the competence of students is the referral for assessing in the form of work competence of what needs to be mastered according to SOP of Hotel Industry [19].

\section{A. Preparation Stage of Linen Cleaning}

The indicators at the preparation stage have been adjusted to grooming standards according to Darsono [20], which includes wearing clean and tidy uniforms, using name tags, looking neat and tidy, etc. The students will get a score when they practice linen cleaning according to the indicators on the assessment, the teacher will check the "competent" column. If, one of the indicators of practice is not carried out, the student does not get a score, then the teacher gives a check to the column "not competent". The preparation stage of linen cleaning can be seen in table 1 :

TABLE I. Preparation Stage of Linen Cleaning Performance ASSESMENT

\begin{tabular}{|c|c|c|c|}
\hline No & Assessing Indicator & Competent & Not \\
\hline \multirow[t]{13}{*}{ A. } & $\begin{array}{c}\text { Preparation Phase of Laundry } \\
\text { Practice } \\
\end{array}$ & & \\
\hline & Grooming & & \\
\hline & $\begin{array}{l}\text { Wear the provided cloth cleanly and } \\
\text { tidily }\end{array}$ & & \\
\hline & Attaching Name Tag to Uniform & & \\
\hline & Looking clean, tidy, and polite & & \\
\hline & For Men, combing the hair neatly. & & \\
\hline & $\begin{array}{l}\text { For Men, not having moustache and } \\
\text { beard. }\end{array}$ & & \\
\hline & $\begin{array}{l}\text { Tidying hair for Women without } \\
\text { Hijab, and for those with Hijab, wear } \\
\text { it tidily }\end{array}$ & & \\
\hline & $\begin{array}{l}\text { Wearing accessories in a simple and } \\
\text { minimal manner. }\end{array}$ & & \\
\hline & Wearing Minimal Make-up & & \\
\hline & Showing the hygiene of Teeth & & \\
\hline & Wearing socks and Van Toefel shoes & & \\
\hline & etc & & \\
\hline
\end{tabular}

\section{B. Process Stage of Linen Cleaning}

Indicators at the process stage are in accordance with hotel SOP and are adjusted to hotel linen handling procedures. Students are competent if they can carry out the process of cleaning linen in accordance with the stages of Collection, Transport Soiled Linen, Sorting of linen, washing / extracting, and Drying, Ironing, Pressing. The process stage of linen cleaning can be seen in table 2 : 
TABLE II. Process Stage of Linen Cleaning Performance ASSESMENT

\begin{tabular}{|c|l|l|l|}
\hline No & Assessing Indicator & Competent & Not \\
\hline B. & $\begin{array}{c}\text { Process Phase of Laundry Practice } \\
\text { Conducting Procedure of Laundry } \\
\text { Practice }\end{array}$ & & \\
\hline & $\begin{array}{l}\text { Collecting dirty linens. } \\
\text { Performing the checking and writing } \\
\text { to room number }\end{array}$ & & \\
\hline & $\begin{array}{l}\text { Transport Soiled Linen } \\
\text { Transporting linen using trolley }\end{array}$ & & \\
\hline & $\begin{array}{l}\text { Grouping Linen according to linen } \\
\text { type }\end{array}$ & & \\
\hline & $\begin{array}{l}\text { Writing down dirty linen } \\
\text { Checking and separating linen } \\
\text { according to its dirtiness } \\
\text { Cleaning particular stain on linen } \\
\text { with chemical }\end{array}$ & & \\
\hline & $\begin{array}{l}\text { Turning over broken or tear linen to } \\
\text { the seamstress }\end{array}$ & & \\
\hline & & & \\
\hline & & & \\
\hline & & & \\
\hline & & & \\
\hline & & & \\
\hline & & & \\
\hline
\end{tabular}

\section{Evaluation Stage of Linen Cleaning}

There are two aspects that must be considered by students in the results of implementing hotel linen washing practices, namely checking and storing linen. The indicators contained in the checking aspect include checking the completeness of the amount of laundry according to the number on the laundry list, tidying up pressed linens, making sure there are no stains that have to be removed again on the linens, checking the folds of linen are clean and tidy, making sure the linen smells like fresh and fragrant. Indicators for linen storage include storing linen on a linen rack according to size, arranging linens with folds of linen facing outwards, taking linen with the FIFO system (first in first out). The evaluation stage of linen cleaning can be seen in table 3:

TABle III. Evaluation Stage of Linen Cleaning Performance ASSESMENT

\begin{tabular}{|c|l|l|l|}
\hline No & \multicolumn{1}{|c|}{ Assessing Indicator } & Competent & Not \\
\hline C & $\begin{array}{l}\text { Evaluation stage of Linen Cleaning } \\
\text { Performance Assessment }\end{array}$ & & \\
\hline & $\begin{array}{l}\text { Checking } \\
\text { Checking the completeness of the } \\
\text { amount of laundry according to the } \\
\text { number in the laundry list }\end{array}$ & & \\
\hline $\begin{array}{l}\text { Tidy up the pressed linen } \\
\text { Storage of linen }\end{array}$ & $\begin{array}{l}\text { Stores linens on a linen rack according } \\
\text { to size }\end{array}$ & & \\
\hline $\begin{array}{l}\text { Arrange linen with the linen folds } \\
\text { facing out }\end{array}$ & & \\
\hline
\end{tabular}

Performance assesment above is designed in checklists. This checklist can be used in observing the performance of students [21]. The use of check lists makes it easy for teachers to assess the skills of students in large numbers. Checklists are more practical if used to deal with a larger number of subjects [22].

The success criteria used in this assessment is "competent" and "not" its mean students will get a score if they have finished practicing according to the indicators in the assessment, if they miss it then they will not get a score [23].

Validation result of Performance assessment that has been conducted by 3 validators, which are assessment experts who is also a Lecturer of Home economics study program and 2 material expert which are the supervisor of housekeeping hotel and the lecturer of Home economics study program concentrated hotel accommodation, resulting the qualification "Very Worthy" for the cleaning of hotel's linen. The achievement is seen from the assessment according several aspects that covers the indicators in performance assessment is in accordance to Hotel's standard operational procedure. Hotel standard operational procedure need to enforced to minimize errors when practicing [24]. The development of performance assessments in accordance with hotel standard operational procedure will help make it easier for teachers to assess and evaluate student learning [22]. Futhermore, The language that's being used is very communicative, making it easier to understand for the students; using terms that very easily to understand for students; the format of instrument is easy to read and easy to understand; instructions for filling the format is clear; also, the scoring rubric is clear and easily to understand for the teachers and students. The research is in accordance with the statement Asiah [25] that, performance assessment covers 3 components of assessing with is content, discussion, and presentation.

According to the percentage of validation result shows that performance assessment shows a "Very Worthy" criteria because it achieved the score of $98 \%$, it refers to the scale [10] that the criteria with the score of $82 \%-100 \%$ is considered the criteria qualification of very worthy validity.

\section{CONCLUSION}

Developing Performance Assessment of Hotel's Linen Cleaning for the competency test of laundry in the housekeeping department, conducted by one assessment experts and two material experts shows that the performance assessments of developed linen assessment is shown as "Very Worthy" to be used, so performance assessment can be used by the teacher when performing competency test for Laundry.

The limitation in this research is conducting feasibility test in the design of performance assessment. Future directions for further research are implementation the performance assessment in linen's cleaning. 


\section{REFERENCES}

[1] L. Powell and S. McGrath, "Skills for human development: transforming vocational education and training," Journal of Vocational Educational \& Training 2020, vol. 72, no. 3, pp. 461-464, 2019.

[2] P.S.A. Pardede and F. Yusrizal, Pelaksanaan Tugas Order Taker Departement Housekeeping Di Nagoya Mansion Hotel \& Residence Batam. Riau: Riau University, 2018.

[3] P.M. Mele, J.M. Gomez, and L. Garay, "To Green or Not to Green: The Influence of Green Marketing on Consumer Behaviour in the Hotel Industry," Journal Sustainability, vol. 11, no. 17, pp. 1-17, 2019.

[4] Bagyono, Manajemen Housekeeping Hotel. Bandung: Alfabeta, 2006.

[5] P. Ekawatiningsih, "Pengembangan Instrumen Penilaian Berbasis Kompetensi untuk Meningkatkan Kualitas Pembelajaran Produktif di SMK," Innovation of Vocational Technology Education, vol. 11, no. 1, 2015.

[6] E. Kosasih, A. Yuniawati, V. Suryaputra, and A. Limijaya, "Model for Calculating Cost of Laundry Services by Considering Environmental Impacts and Costs," Journal of Accounting and Investment, vol. 20, no. 2, pp. 173-107, 2019.

[7] T. Adiguzel, "Use of Audio Modification in Science Vocabulary Assessment," Eurasia Journal of Mathematics, Science \& Technology Education, vol. 7, no. 4, pp. 215-225, 2011.

[8] S.N. Sobariah, Pengembangan Alat Penilaian Praktik Cleaning Bathroom Berbasis Standar Operasional Prosedur Hotel Di Smk 45 Lembang. Bandung: Universitas Pendidikan Indonesia, 2018.

[9] A. Fersanti, "Pengembangan Performance Assessment untuk Mengukur Keterampilan Proses dalam Menggunakan Alat Ukur Panjang pada Siswa X-MIA Di SMA Negeri 5 Purworejo Tahun Pelajaran 2014/2015,” Radiasi: Jurnal Berkala Pendidikan Fisika, vol. 5, no. 1, pp. 4-7, 2014.

[10] C. Subagia, "Pengembangan instrumen penilaian kinerja (performance assessment) untuk menilai keterampilan proses sains peserta didik pada materi reaksi eksoterm dan endoterm kelas xi sma," UNESA Journal of Chemical Education, vol. 6, no. 3, 2017.

[11] I. Ardli, A.G. Abdullah, S. Mudalifah, and A. Ana, "Perangkat Penilaian Kinerja untuk Pembelajaran Teknik Pemeliharaan Ikan," Innovation of Vocational Technology Education, vol. 8, no. 2, 2012.

[12] A. Marhaeni, I. Kusuma, N. Dewi, and A. Paramartha, "Using performance assessment to empower students' learning ownership and promote achievement in EFL writing courses," International Journal of Humanities, Literature \& Arts, vol. 2, no. 1, pp. 9-17, 2019.

[13] Y. Jubaedah, Model Penilaian Keahlian Tata Busana Berbasis Standar Kompetensi Nasional di Sekolah Menengah Kejuruan.Program Studi Pengembangan Kurikulum Sekolah Pascasarjana Universitas Pendidikan Indonesia. Bandung: Kurikulum Sekolah Pascasarjana Universitas Pendidikan Indonesia, 2009

[14] N.R. Rinekasari, Y. Jubaedah, and S.N. Sobariah, "Standard Operating Procedure of Housekeeping Adaptation: The Development of Assessment Tools in Cleaning Bathroom Practices at Vocational High School," KnE Social Sciences, pp. 150-161, 2019.

[15] Sudjana, Metode Statistika. Bandung: Tarsito, 2005.

[16] S. Ariska and A.M. Rifiyan, "Management of Linen Housekeeping in the Premiere Hotel Pekanbaru,” Jom Fisip, vol. 3, no. 2, 2016.

[17] N.W. Suwithi, Akomodasi Perhotelan jilid 1. Jakarta: Depdiknas, 2008.

[18] E. Bhatnagar and D. Nim, "Impact of Housekeeping Services and Practices on Customer Satisfaction and Repeat Business," Prabandhan Indian Journal of Management, vol. 12, no. 8, pp. 46-57, 2019.

[19] N. Syarifah, Penerapan Standar Operasional Prosedur (SOP) dalam meningkatkan kinerja pegawai pada Seksi Pendidikan Diniyah dan Pondok Pesantren di Kantor Kementerian Agama Kota Surabaya. Surabaya: UIN Sunan Ampel Surabaya, 2019.

[20] A. Darsono, Housekeeping Hotel. Jakarta: PT Gramedia Pustaka Utama, 2011.

[21] I. Basuki and Hariyanto, Assesment Pembelajaran. Bandung: Remaja Rosdakarya, 2016.

[22] S.M. Nur, "Pengembangan perangkat penilaian psikomotorik pada peserta didik," Jurnal Biotek, vol. 3, no. 99, pp. 151-169, 2015

[23] S.F. Yusuf, "Designing Performance Assessment for Manual Polishing Practice in Vocational High School," International Conference on Technical and Vocational Education and Training 2018, KnE Social Science, pp. 138-149, 2019.

[24] H. Haryati, Pengembangan Instrumen Penilaian Berbasis Kompetensi pada Praktikum Pemrograman Web di SMK," Jurnal Pendidikan, vol. 6 , no. 2, pp. 1-13. 2017.

[25] H.A. Asiah, E. Susilaningsih, and M. Nuswowati, "Inovasi Mode Penilaian Proses pada Pembelajaran Kimia Untuk Mengukur Keterampilan Laboratorium dan Aktivitas Siswa," Jurnal Inovasi Pendidikan Kimia, vol. 11, no. 2, 2017. 